\author{
А. В. Носовський, Н. А. Кравченко \\ Державний науково-технічний центр \\ з ядерної та радіаційної безпеки
}

\section{Система показників ефективності діяльності наукових співробітників}

Наведено основні рекомендації зі створення та впровадження в практичне застосування Державним науково-технічним центром зядерної та радіаційної безпеки методики оцінювання ефективності діяльності наукових співробітників у процесі проведення їх періодичної атестації.

Ключ о в і с ло в а: наукова діяльність, показники ефективності наукової діяльності, атестація наукового персоналу.

\section{А. В. Носовский, Н. А. Кравченко}

\section{Система показателей эффективности деятельности научных сотрудников}

Приведены основные рекомендации по внедрению в практическое использование Государственным научно-техническим центром по ядерной и радиационной безопасности методики оценки эффективности деятельности научных сотрудников при проведении периодической аттестации.

Ключевые слова: научная деятельность, показатели эффективности научной деятельности, аттестация научного персонала.
I снує досить велика кількість методик оцінки ефективності діяльності наукових організацій [1]-[5], однак показники рівня наукового потенціалу цих організацій найчастіше описують лише економічний бік питання. Без уваги залишається неекономічна, якісна складова науково-технічної діяльності. Оцінюючи діяльність співробітника будь-якої наукової організації, необхідно розділяти науково-дослідну й науково-організаційну, управлінську діяльність, яка далеко не завжди може бути оцінена за кінцевими результатами.

Державний науково-технічний центр з ядерної та радіаційної безпеки (ДНТЦ ЯРБ) створено в лютому 1992 р. на підставі постанови Кабінету Міністрів України від 03.02.1992 р. № 52 з метою всебічної науково-технічної підтримки державного регулювання ядерної та радіаційної безпеки, спрямованої на захист населення й довкілля від радіаційного впливу техногенного походження. Основними завданнями ДНТЦ ЯРБ [6] є:

наукова, аналітична, експертна, інформаційна й консультативна підтримка державного регулювання ядерної та радіаційної безпеки в сфері використання ядерної енергії;

науково-технічне обгрунтування принципів, критеріїв і вимог ядерної та радіаційної безпеки;

оцінка поточного стану ядерної та радіаційної безпеки ядерних установок, об’єктів для поводження з радіоактивними відходами, радіаційних технологій, а також ризиків від їхнього впровадження;

узагальнення досвіду діяльності в сфері використання ядерної енергії, освоєння й застосування передового досвіду з аналізу й оцінки безпеки;

підготовка аналітичних та інформаційних матеріалів про стан ядерної та радіаційної безпеки в сфері використання ядерної енергії.

Для підвищення ефективності й подальшого розвитку науково-технічного потенціалу ДНТЦ ЯРБ спільним наказом Держатомрегулювання й Національної академії наук України (НАН України) від 25.11.08 № 612/192 ДНТЦ ЯРБ надано статус подвійного підпорядкування Держатомрегулюванню й Національній академії наук України. За науковим напрямком діяльності підприємства ДНТЦ ЯРБ уведено до складу Відділення ядерної фізики та енергетики НАН України [7].

Для розширення спектра науково-технічної діяльності в рамках двосторонніх договорів ДНТЦ ЯРБ співпрацює з низкою національних наукових інститутів НАН України, Академії медичних наук України, вищих навчальних закладів України, а також з організаціями науково-технічної підтримки регулювальних органів США, Німеччини, Франції, Бельгії, Чехії, Болгарії, Угорщини, І̇талії, Японії, Словаччини, Білорусії й Росії. У листопаді 2010 р. ДНТЦ ЯРБ став асоційованим членом Европейського співтовариства організацій з технічної безпеки ETSON. Мета діяльності ETSON - поширення в Свропі співпраці між організаціями науково-технічної підтримки в сфері ядерної безпеки шляхом систематичного обміну результатами науково-дослідних робіт, досвідом, пов'язаним з експлуатацією ядерних установок і оцінкою безпеки, а також шляхом поширення й гармонізації практики оцінки ядерної безпеки, стимулювання розробки й впровадження Європейських дослідницьких програм [8].

У 2010 р. ДНТЦ ЯРБ пройшов державну атестацію науково-технічних установ НАН Україны. За результатами роботи експертної комісії при Відділенні ядерної фізики та енергетики НАН України Президією Національної 
академії наук України ухвалено рішення про включення ДНТЦ ЯРБ до Державного реєстру наукових установ, яким надається підтримка держави.

Відповідно до Закону України «Про наукову й науковотехнічну діяльність», а також Постанови Кабінету Міністрів України від 13 серпня 1999 р. № 1475 «Про затвердження положення про атестацію наукових працівників» у 2007 р. розроблено й затверджено «Положення про атестацію наукового персоналу ДНТЦ ЯРБ» (далі - Положення) [9], на підставі якого з установленою періодичністю проводиться атестація всього наукового персоналу з метою визначення відповідності кваліфікації науковця займаній посаді. Для організації й проведення атестації в ДНТЦ ЯРБ створено постійно діючу атестаційну комісію з числа висококваліфікованих науковців.

Згідно з Положенням науковці, що підлягають атестації, складають індивідуальний звіт про наукову діяльність - перелік основних наукових результатів, а саме:

участь у виконанні НДР і розробці нормативних документів;

участь у виконанні державних експертиз ядерної та радіаційної безпеки;

участь у наукових конференціях, семінарах, симпозіумax;

список опублікованих наукових праць;

результати науково-організаційної діяльності;

інші наукові результати (підготовка дисертацій, рецензування наукових праць, авторські посвідчення, патенти, підготовка наукових кадрів, викладацька діяльність, участь у роботі наукових організацій, спеціалізованих вчених рад, науково-технічних рад тощо).

Досвід проведення атестації показав, що Положення [9] не повною мірою враховує специфіку роботи фахівців ДНТЦ ЯРБ, тому з'явилася потреба в розробці системи показників ефективності роботи наукових співробітників. Якщо говорити в цілому про принципи, на яких будується процедура оцінки наукового персоналу, то в першу чергу слід зазначити, що будь-яка оцінка персоналу покликана відповісти на запитання про те, наскільки ефективна робота співробітників, і надати досить інформації для прийняття наступних управлінських рішень. При цьому під ефективністю може розумітися й досягнення необхідних виробничих, якісних показників, і оптимальна відповідність професійних навичок і особистісних якостей займаній науковій посаді. Ряд можливих управлінських рішень може охоплювати зарахування в кадровий резерв на посаду вищого рівня, переведення на іншу посаду, преміювання, установлення або зняття надбавок до посадового окладу за досягнення в роботі, підвищення кваліфікації, звільнення науковця, визнаного не відповідним до займаної посади, та ін.

Оцінка якості діяльності окремого наукового співробітника й наукових колективів - актуальне й досить складне завдання. Можливі різні варіанти оцінки будь-якого виду творчої діяльності; однак у всіх їі сферах найбільш об'єктивною є все-таки оцінка за кінцевим результатом, а не за процедурою його досягнення й витраченим на це зусиллям.

Аж до початку XX ст. наукою займалося невелике коло людей, шедших у неї за покликанням, тому вагомість внеску вченого оцінювалася науковим співтовариством фактично лише по змістовних якісних критеріях. Коли ж заняття наукою стало більш масовим явищем, одні якісні критерії оцінки наукової діяльності виявилися вже недостатніми: усе настійнішою вимогою часу стає необхідність оцінки з використанням кількісних параметрів, що характеризують наукову діяльність. В Україні подібна методологія потрібна ще й тому, що вчені титули й звання нерідко служать додатком до іміджу чиновників, які найчастіше ніякого відношення до науки не мають. У пошуках критеріїв подібної оцінки в наукометрії з'явився термін «індекс цитованості вченого». Фактично це не що інше, як кількість посилань на всі роботи даного дослідника, які він виконав у відповідній галузі наукової діяльності за конкретний період. Цей показник набув досить широкої популярності, але ставитися до нього слід з обережністю: якщо згадати історію науки, то були часи, коли повсюдно цитували класиків марксизму-ленінізму, а сьогодні їх ніхто не згадує.

Як і ефективність роботи наукової організації в цілому, ефективність праці кожного окремого науковця характеризується багатьма показниками, причому кожний з цих показників має певну вагу. Безумовно, говорити про ріст ефективності наукової діяльності можна тільки в тому випадку, якщо жоден з окремих показників не знизився. Однак, розглядаючи ефективність праці кожного науковця, доцільно оцінювати не тільки результати його особистої праці, а внесок даного співробітника в науковий потенціал своєї організації. У такому випадку навіть зниження одного або кількох окремих показників не буде означати зниження даного внеску, якщо воно компенсується зростанням інших окремих показників.

У зв'язку зі специфікою науково-технічної продукції ДНТЦ ЯРБ, під науково-технічною діяльністю розумітимемо діяльність з проведення прикладних досліджень і розробок з метою створення нових або вдосконалення існуючих методів і засобів проведення оцінки рівня ядерної та радіаційної безпеки. Науково-технічна діяльність охоплює також роботи з науково-методичного, програмного, організаційно-методичного й технічного забезпечення проведення досліджень і розробок, а також їх поширення й застосування результатів [8]. Під розробками розуміється діяльність, спрямована на створення або вдосконалення способів і засобів здійснення процесів у галузі проведення оцінок ядерної та радіаційної безпеки, зокрема на створення нових методів, моделей, критеріїв безпеки.

Під час проведення чергової атестації наукового персоналу ДНТЦ ЯРБ було би корисним виконати оцінку ефективності наукових співробітників за формальними ознаками, щоб виявити тих з них, хто одержує відповідну зарплату, але реально не займається науковою працею. Критерієм для переведення на технічну посаду може служити відсутність публікацій у наукових журналах протягом трьох років, що передують року проведення атестації. Крім цього, доцільно було б також понизити на посаді тих наукових співробітників, які показали за результатами атестації найгірші результати й, навпаки, підвищити на посаді співробітників, що показали найкращі результати. Це дозволило б заохотити тих, хто добре працює, і стимулювати тих, хто працює недостатньо активно, до підвищення інтенсивності наукової праці. Підсумки атестації слід зробити надбанням гласності, розміщаючи їх на сайті ДНТЦ ЯРБ.

Практика показує, що скрізь, де вводилася система оцінки, вона сприяла зростанню результативності праці [10]. Пропонована система оцінки не ставить своєю метою дати об'єктивну оцінку наукового рівня роботи співробітника й значимості його результатів. Це завдання неможливо розв'язати настільки простими методами. Ї̈ї мета, за великим рахунком, в іншому - у поділі наукових 
співробітників на групи залежно від результатів їх праці. Це дозволить не тільки скласти в цілому правильне уявлення про працездатність і результативність роботи конкретних наукових співробітників і наукових підрозділів ДНТЦ ЯРБ у цілому, але й дасть змогу оперативно підтримати результативно працюючих фахівців (наприклад, переведенням на вищі посади або встановленням надбавок). До першої групи, найменш ефективної, слід віднести тих, чия діяльність на посаді наукового співробітника практично не дає видимої віддачі; до другої - наукових співробітників, які одержують наукові результати середньої значимості; до третьої - найбільш активно працюючих співробітників, що одержують результати, які привертають увагу досить широкої наукової аудиторії.

Отже, під науково-технічною ефективністю діяльності наукового співробітника розуміється сукупність показників, що характеризують ступінь його участі в науково-технічній діяльності організації. Формальні критерії оцінки роботи наукових співробітників достатньо відомі - це кількість статей у наукових журналах, індекс цитованості, визнання з боку наукової громадськості в самому широкому сенсі (премії, нагороди тощо) та ін. У цьому випадку йдеться про початковий етап оцінки ефективності наукового потенціалу, тому бажано використовувати тільки ті формальні показники, одержання яких не потребує великих зусиль й доступу до спеціалізованих баз даних.

Пропонована методика призначена для забезпечення єдиного підходу, що дозволяє визначити ефективність діяльності наукових співробітників ДНТЦ ЯРБ під час періодичної атестації. Ефективність наукової діяльності визначається простим підсумовуванням балів, якими оцінені відповідні показники.

Для того щоб привести всі показники до єдиного базису, доцільно використовувати бальну оцінку [11]. При цьому виникає небезпека зайвої суб’єктивності такої оцінки. Щоб уникнути цього, необхідно використовувати відповідні шкали, які доцільно розробити в ході впровадження методики на практиці. Ефективність конкретного наукового співробітника може обчислюватися за формулою

$$
E=\sum_{1}^{n} K_{n},
$$

де $K$ - значення $n$-го показника в балах.

Для оцінки внеску співробітників у науковий потенціал ДНТЦ ЯРБ треба чітко сформулювати основні компоненти наукового потенціалу. У рамках науково-технічних напрямків діяльності ДНТЦ ЯРБ при визначенні індивідуальних показників ефективності роботи наукових співробітників доцільно використовувати такі критерії оцінки:

виконання складних експертиз з проведенням перевірочних розрахунків, обгрунтувань, розробкою нових моделей тощо;

виконання НДДКР;

розробка нормативних і методичних документів;

роботи з валидации й верифікації розрахункових програм, розробка розрахункових моделей;

участь у міжнародних наукових проектах і програмах;

участь в інспекційних перевірках на об'єктах з ядерними та радіаційними технологіями;

підготовка наукових рецензій на монографії, статті, дисертації, проекти нормативних і методичних документів, стандартів МАГАТЕ й т. ін.; кількість публікацій у рецензованих українських та іноземних наукових журналах;

участь у підготовці монографій, підручників;

участь у національних і міжнародних наукових конференціях;

підвищення кваліфікації на курсах, семінарах тощо; навчання в аспірантурі, індивідуальна робота над дисертацією (на здобуття наукового ступеня);

захист докторської або кандидатської дисертації, одержання вчених звань;

підготовка й проведення наукових і навчальних семінарів;

наукове керівництво підготовкою дисертаційних робіт;

кількість аспірантів, докторантів і здобувачів, що захистили під керівництвом наукового співробітника дисертації на здобуття вчених ступенів;

робота з молодими спеціалістами, керівництво практикою студентів, наставництво;

кількість студентів, що захистили випускні кваліфікаційні роботи під керівництвом наукового співробітника;

кількість молодих спеціалістів і студентів, що підготували під керівництвом наукового співробітника наукові статті й тези доповідей на наукових конференціях;

кількість молодих спеціалістів і студентів, що підготували під керівництвом наукового співробітника наукові праці, які зайняли призові місця на конкурсах наукових праць;

опонування кандидатських і докторських дисертацій; педагогічна діяльність у вищих навчальних закладах;

участь у конкурсах наукових праць, премії за наукові праці;

співпраця з вітчизняними й закордонними науковими інститутами, організаціями;

участь у діяльності національних і міжнародних науково-технічних громадських організацій;

організаційна й управлінська наукова діяльність (підготовка періодичних звітів про наукову діяльність організації, наукові переклади, залучення фінансових коштів зовнішніх замовників науково-технічної продукції та ін.);

кількість виступів на телебаченні, радіо, круглих столах, публікація статей у 3Мї, читання лекцій для населення, участь у виставках, підготовка повідомлень на сайт.

Даний перелік показників можна розширити в ході практичного відпрацьовування методики оцінки, в основі якої лежить присуджування балів за наявність тих або інших показників і підсумовування цих балів. Сума й буде тою самою оцінкою результативності наукової роботи 3 погляду формальних показників.

Основною науковою продукцією ДНТЦ ЯРБ є науково-технічні оцінки (експертизи) у сфері ядерної й радіаційної безпеки. Тому необхідно ввести показник $K_{\text {екс }}$, що характеризує загальну кількість виконаних за звітний період експертиз, рівень новизни й складності наукових і науково-технічних експертних робіт порівняно зі світовим, орієнтованість на досягнення кінцевих результатів в галузі безпечного використання атомної енергії. Цей показник можна обчислити за формулою

$$
K_{\text {екс }}=\sum_{1}^{i} R_{i},
$$

де $R$ - показник новизни й складності $i$-тої експертизи, який приймається від 0,5 до 5 на розсуд керівника структурного підрозділу. 
Крім того, при атестації наукового співробітника необхідно враховувати його залучення у виконання експертизи на рівні ї̈ керівника або виконавця (співвиконавця). Для керівника експертизи пропонується значення $K_{i \text { екс }}$ збільшувати на коефіцієнт 2, для керівника за напрямком при проведенні комплексної експертизи - 1,5, для виконавця -1.

Науковий проект - це проект, фінансований за підсумками тендера або іншого конкурсу. Статус керівника наукового проекту означає здатність ученого ставити завдання й пропонувати алгоритми їх розв'язку. Виходячи 3 цього, слід присуджувати 10 балів за керівництво бюджетною, госпрозрахунковою НДР або за керівництво міжнародним проектом, 5 балів - за керівництво конкретним науковим завданням при виконанні НДР, за участь у проектах у якості виконавця - 2 бали. Те саме стосується розробки нормативних і методичних документів.

Основним продуктом діяльності наукового співробітника, з формальної точки зору, є наукові праці (статті в рецензованих наукових журналах). Просто підсумувати кількість статей, незалежно від того, який рейтинг наукового журналу, в якому вони опубліковані, мабуть, неправильно. Значимість наукового журналу прийнято виражати через імпакт-фактор. Цей показник говорить про те, як часто в середньому посилаються на статті, опубліковані в даному журналі. Тому, щоб внести корективи в найпростішу методику і якимось чином урахувати якість статей, можна підсумувати не кількість статей, а імпакт-фактори журналів, у яких вони опубліковані. Можна й далі ускладнювати цю методику, наприклад, враховуючи загальну кількість авторів, положення оцінюваного співробітника в списку авторів, але тут відкривається досить широке поле для сваволі, а система оцінки має бути максимально простою. Представляється доцільним умовно поділити журнали, в яких публікуються наукові співробітники ДНТЦ ЯРБ, на дві групи, і кожній з них присвоїти відповідні коефіцієнти:

вітчизняні спеціалізовані наукові журнали, в яких статті або анотації до них наводяться англійською мовою, - за публікацію статті в такому журналі пропонується присуджувати 10 балів;

іноземні наукові журнали, що входять до категорії найбільш авторитетних у сфері ядерної та радіаційної безпеки, - 20 балів.

Публікації в науковій періодиці Україні враховуються, якщо журнал включений до Переліку наукових спеціалізованих видань ВАК України, в яких можуть бути опубліковані основні наукові результати дисертацій на здобуття наукового ступеня кандидата або доктора наук. Для статей, написаних у співавторстві, бал за публікацію ділиться на кількість авторів публікації.

За видані монографії, підручники й навчальні посібники встановлюється бал, який дорівнює обсягу видання в умовних друкованих аркушах, помноженому на 10. За наявності співавторів бали кожному з них установлюються пропорційно обсягу написаного матеріалу. Укладачі колективних монографій і збірників одержують по 0,5 балів за авторський аркуш, титульний редактир - 10 балів.

Крім публікацій у наукових журналах, існує й інший спосіб оповіщення наукової громадськості про результати своєї роботи - участь у наукових конференціях. За публікацію в збірниках тез конференції в сфері ядерної енергетики, що практикують реальний відбір представлених тез, можна було б присуджувати 5 балів. Окремо не- обхідно враховувати участь у конференціях в особливому статусі - запрошеного доповідача, оскільки такий статус передбачає, що роботи спеціально запрошуваного наукового співробітника викликають особливий інтерес організаторів міжнародної конференції. За участь у конференції в статусі запрошеного доповідача пропонується присуджувати 20 балів. За наявності співавторів бал за доповідь ділиться на кількість авторів доповіді й для доповідача множиться на 1,5, а для співавторів - на 0,5.

Виконуючи складні експертні оцінки, багатьом науковим співробітникам доводиться проводити перевірочні розрахунки з використанням розрахункових комп'ютерних програм, їх валідацию й верифікацію, розробляти нові моделі. За участь у подібних роботах пропонується встановити показник на рівні від 1 до 10 балів залежно від складності й ступеня новизни.

В інтегральному показнику ефективності роботи наукового співробітника має враховуватися ступінь його залучення до діяльності за міжнародними науковими проектами й програмами. В разі виконання НДР по міжнародній тематиці ми вже оцінювали діяльність керівників і виконавців проектів, але є такі роботи (в основному підготовчі та організаційні), які, як правило, рідко враховуються, але теж підлягають конкретній оцінці. Це рутинні роботи з передпроектної підготовки, переклади, листування, підготовка звітів, узгодження ціни тощо. За активну участь у подібних роботах пропонується встановити значення показника від 0,5 до 2.

Будь-який науковий співробітник зобов'язаний передавати свої знання й досвід молодим спеціалістам [12]. Шоб забезпечити ефективний добір молодих спеціаластів, ДНТЦ ЯРБ приймає для проходження практики в наукових підрозділах студентів провідних вищих навчальних закладів України за напрямками освіти; після успішного проходження практики багато хто з них залишається для подальшої роботи в організації. Кожному молодому спеціалісту призначається наставник з числа висококваліфікованих, досвідчених і авторитетних науковців, що мають стаж роботи за спеціальністю в ДНТЦ ЯРБ не менше трьох років. Наставник розробляє індивідуальну програму підготовки молодого спеціаліста, спрямовану на початкову підготовку на робочому місці:

засвоєння початкових знань норм, правил і стандартів з ядерної та радіаційної безпеки;

ознайомлення зі структурою, основними напрямками й видами діяльності ДНТЦ ЯРБ;

ознайомлення з документацією системи якості ДНТЦ ЯРБ, яка поширюється на підрозділ;

засвоєння методичного, наукового й технічного забезпечення діяльності ДНТЦ ЯРБ;

залучення до розробки норм, правил і стандартів з ядерної та радіаційної безпеки, виконання науково-дослідних робіт і державних експертиз з ядерної та радіаційної безпеки.

Після закінчення періоду підготовки, установленого програмою, молодий спеціаліст складає іспит на допуск до самостійної роботи [13]. Даний напрямок діяльності наукового співробітника як наставника оцінюється 5 балами за кожного молодого спеціаліста. Якщо студент готовить у ДНТЦ ЯРБ бакалаврську або магисторську роботу під керівництвом наукового співробітника, ця діяльність наукового співробітника оцінюється ще 5 балами за умови позитивного захисту студентом випускної кваліфікаційної роботи. Якщо під час роботи в ДНТЦ ЯРБ студенти 
підготували під керівництвом наукового співробітника наукові статті й тези доповідей на наукових конференціях, ця його діяльність оцінюється 5 балами за кожну студентську роботу, а якщо студентська робота зайняла призове місце на конкурсах наукових праць, - додатковими 10 балами.

Навчання наукового співробітника на курсах підвищення кваліфікації, в аспірантурі, а також індивідуальна робота над дисертацією оцінюється 5 балами, наукове керівництво підготовкою дисертаційних робіт - 20 балами за кожного аспіранта (здобувача). За захист кандидатської й докторської дисертації дисертантові й науковому керівникові встановлюється відповідно 50 і 100 балів, за одержання вчених звань старшого наукового співробітника або доцента - 30, професора - 80; за участь наукового співробітника в опонуванні кандидатських дисертацій 10 , докторських - 20; за підготовку наукових рецензій на проекти нормативних документів, монографії, статті, дисертації, проекти стандартів МАГАТЕ - 5 (за кожну рецензію); за педагогічну діяльність у виших навчальних закладах - 10; за розробку нового курсу лекцій на навчальних семінарах, що читається вперше, - 10; за доробку науково-освітнього курсу, що передбачає введення нового актуального матеріалу, - 5; за організаційну діяльність по підготовці й проведенню наукових і навчальних семінарів - 5 балів.

Участь наукового співробітника в інспекційних перевірках, проведених Державним комітетом ядерного регулювання України на об’єктах, що використовують ядерні й радіаційні технології, також можна віднести до науково-технічної діяльності. Кожному учасникові інспекції за поданням звіту про виконану роботу встановлюється по 5 балів.

Визнання з боку наукового співтовариства виражається звичайно у формі присудження премій або нагород. Підготовка необхідних матеріалів для участі в конкурсах наукових праць оцінюється 10-50 балами залежно від рівня конкурсу. Пропонується присуджувати за премії місцевого рівня (лауреатам конкурсів молодих спеціалістів, відомчих премій) 20 балів, за премії міжвідомчого масштабу (включаючи премії Академії наук) - 50, за премії й нагороди України - 100 балів.

Організаційна й управлінська наукова діяльність (підготовка періодичних аналітичних звітів про наукову діяльність організації, наукові переклади, залучення фінансових коштів зовнішніх замовників науково-технічної продукції) оцінюється 5-20 балами залежно від значимості й складності.

Потрібно стимулювати й активну участь у діяльності національних і міжнародних науково-технічних громадських організацій. Якщо науковий співробітник входить до складу правління або інших керівних органів громадської організації, його діяльність оцінюється 5 балами; якщо є членом ученого спеціалізованого ради із захисту дисертаційних робіт, - 20, науково-технічної або вченої ради інших організацій - 5 балами. Члену редакційної ради періодичного видання (журналу) нараховується 10 балів, головному редактору й заступникові головного редактора - 25. Діяльність, пов’язана з популяризацією серед населення результатів роботи організації - виступ на телебаченні, радіо, круглих столах, статті в ЗМї, лекції для населення, участь у виставках, підготовка повідомлень на сайт ДНТЦ ЯРБ, - оцінюється 2 балами за участь в одному заході.
3 метою підвищення ефективності керівництва науково-технічною діяльністю, індивідуальний показник ефективності роботи керівників наукових підрозділів установлюється шляхом додавання 50 \% індивідуального показника, обчисленого за наведеними процедурами, і $75 \%$ середнього показника ефективності роботи науковців підрозділу.

Показник результативності науковців, що працюють за сумісництвом, множиться на коефіцієнт, який дорівнює відношенню тривалості робочого часу сумісника за місяць до нормальної тривалості робочого часу штатного співробітника на аналогічній посаді. При цьому до розрахунку беруться тільки ті показники, які отримані при роботі в організації й офіційно до неї віднесені.

\section{Список літератури}

1. Правила оценки результативности деятельности научных организаций, выполняющих научно-исследовательские, опытноконструкторские и технологические работы гражданского назначения. - Утв. постановлением Правительства Российской Федерации от 8 апреля 2009 г. № 312.

2. Типовая методика оценки результативности деятельности научных организаций, выполняющих научно-исследовательские, опытно-конструкторские и технологические работы гражданского назначения. - Утв. приказом Министерства образования и науки Российской Федерации от 14 октября 2009 г. № 406.

3. Лисицына $E$. Рейтинговая система оценки научно-исследовательской деятельности / Е. Лисицына, К. Молчанов // Высш. образование в России. - 2005. - № 12. - С. 64-66.

4. Об утверждении Методических рекомендаций по оценке эффективности научных, научно-технических и инновационных разработок: Постановление Национальной академии наук Беларуси, Государственного комитета по науке и технологиям Республики Беларусь от 03.01.2008 № 1/1.

5. Методика оценки деятельности научных организаций. Утв. приказом Министра образования и науки Республики Казахстан от 14 июня 2005 г. № 404.

6. Статут Державного підприємства «Державний науковотехнічний центр з ядерної та радіаційної безпеки». - Погоджено Президентом Національної академії наук України 15.09.2009 та затверджено Головою Державного комітету ядерного регулювання України 01.10.2009.

7. Валігун Н. П., Воробей І. І., Кравченко Н. А., Артюшенко В. В. Підсумкові результати науково-технічної діяльності ДНТЦ ЯРБ за 2009 рік // Ядерна та радіаційна безпека. - 2010. -Вип. 2 (46). - C. 3-8.

8. Неклюдов І. М., Громов Г. В., Валігун Н. П., Носовський А. В. Щодо вдосконалення системи науково-технічної підтримки Держатомрегулювання України // Ядерна та радіаційна безпека. - 2009. - Вип. 4. - С. 3-9.

9. Система управління якістю. Положення про атестацію наукового персоналу ДНТЦ ЯРБ: ПЛ 6.2.2/520.028:2010 - К.: ДНТЦ ЯРБ, $2010-15 \mathrm{c}$.

10. Сидоренко Г. И. Об эффективности научной деятельности (оценка фундаментальных и прикладных исследований) // Наука и инновации. - 2004. - № 5. - С. 46-48.

11. Головкин Б. Г. Оценка вклада ученых в науку // Вестник Рос. академии наук. - 2001. - Т. 71, № 7. - С. 656-657.

12. Носовский А. В., Клевцов А. Л., Кравченко Н. А. О системе управления ядерными знаниями в регулирующей деятельности // Ядерна та радіаційна безпека. - 2010. - Вип. 1(45). - С. 29-34.

13. Система управління якістю. Положення про професійну підготовку та підвищення кваліфікації наукового персоналу: ПЛ 6.2.2/520.008:2010. - К.: ДНТЦ ЯРБ, 2010. - 18 с.

Надійшла до редакції 22.12.2010. 